УДК 7.067.6

\title{
КИТЧ В СОВРЕМЕННОМ ИНФОРМАЦИОННОМ ПОЛЕ
}

\section{Фирсова Дарья Игоревна}

Санкт-Петербургская Академия Художеств имени Ильи Репина

\begin{abstract}
Аннотация: статья посвящена рассмотрению роли китча в современном информационном поле. Поднимается проблема поглощения предметов искусства культурой китча посредством использования избранных артефактов индустрией развлечений. Названы пути превращения образцов высокой культуры в китч и описаны наглядные проявления процесса. Проведены социологические исследования, выявляющие последствия феномена. Обозначены положительные и отрицательные эффекты явления.
\end{abstract}

Ключевые слова: китч, элитарная культура, искусствознание, трансформация, современность.

\section{KITSCH IN THE CONTEMPORARY INFORMATION FIELD}

\section{Firsova Darya Igorevna}

Abstract: the article is devoted to the role of kitch in contemporary informative field. The question of conversion of art objects into kitch is discussed for it becomes possible when the entertainment industry absorbs some preferred works of art. The ways of this transformation as well as examples of its demonstration are examined. In order to reveal the aftereffect of this phenomenon special sociological studies were carried out. As a result, positive and negative impact have been traced.

Key words: kitch, turning into kitch, art criticism, transformation, contemporary.

Хотя изучение проблемного поля китча началось ещё в середине XIX века, оценка явления остается проблематичной ввиду сложности выработки критериев и колеблется от тотального негативизма до полного или частичного принятия. Тем не менее, статья преследует цель не решения этой проблемы, а лишь теоритического установления путей использования артефактов 
культурой китча и последствий явления, сказывающихся на взаимоотношении искусства и человека.

Зародившийся в Древнем Риме и характерный для последующих эпох, только во второй половине XIX века китч начинает постепенно менять свою природу, подстраиваясь под складывающиеся капиталистические общества Второго промышленного переворота. Для них было характерно усложнение социальной стратификации посредством повышения уровня урбанизации городов в связи с ростом спроса на рабочую силу. Рост среднего класса обеспечивался за счет притока жителей деревень и сёл, которые веками воспринимали фольклор и были носителями соответствующей культуры. Попав в город, эти новые горожане подвергались аккультурации и приобщались к прежде неизвестной и недосягаемой городской культуре посредством СМИ, доступного начального образования. Сохранивший неразвитый эстетический вкус, но воспринявший образцы высокой культуры как характеристику элитарности, новый средний класс определил спрос на вещи низкого качества и легкой доступности, содержащие при этом фрагментарную репрезентацию артефактов высокого искусства, призванных продемонстрировать новый статус потребителя. Намерение приобщения к элитарному искусству, сочетаемое с отсутствием опыта оценки эстетических достоинств предмета, симбиоз городской и фольклорной культур с претензией на роскошь стали двигателем перерождения китча в новое культурное образование, основными характеристиками которого стали массовость, вульгарное использование символов элитарной культуры, «вульгарное прочтение исторических стилей и заимствование их элементов»[1, с. 12]одновременная противоположность высокому искусству, «использование готовых элементов как знаков роскоши и высокого стиля» $[1$, с. 12], ориентированность на коммерческий успех, серийный выпуск вещей.

Рынок двадцать первого века продолжает активно предлагать широкий спектр предметов, принадлежащих к культуре китча, при этом предельно эксплуатируя предметы искусства в коммерческих целях посредством китчевой репродукции. Явление широкого распространения эрзацев становится наиболее характерно именно для двадцать первого века, превращаясь само и превращая искусство в тренд моды.

Основным потребителем китчевого искусства является молодёжь, проявляющая наибольшую восприимчивость к материальному. В связи с этим 
отмечается приобщение широких кругов социальной группы к искусству посредством китча. Рассмотрим возможные последствия.

Так как китч имитирует высокие образцы искусства и создает культурные бренды, напрашивается тезис о том, что он имеет духовнонравственный потенциал с точки зрения массового вкуса, то есть способствует приобщению молодёжи к искусству и обеспечивает широкий доступ к произведениям мировой художественной культуры, пускай и в репродуцированном, фрагментарном виде.

С целью эмпирической проверки тезиса референтной группе, состоящей из 50 человек возрастом от 14 до 24 лет, были предложены следующие изображения: «Джоконда» Леонардо да Винчи, «Звездная ночь» Винсента Ван Гога, «Поцелуй» Густава Климта и другие (всего десять), наиболее часто подвергающиеся эксплуатации. Экзаменуемые, оценивая личный уровень информированности относительно представленных работ, могли выбрать один из четырех вариантов ответа: знаком(а) с автором и названием, знаком(а) с названием, но не знаю автора или наоборот, знаком(а) с изображением, но не знаю автора и название, никогда не видел(а) изображение.

Итогом опроса стало выявление следующих показателей: двадцать восемь представителей группы действительно знакомы с представленными художественными произведениями, их автором и названием, один из опрошенных никогда не был знаком хотя бы с одним из произведений и ничего не знаем о нём, примерно пополам разделилось количество подростков, которым неизвестны автор и/или название.

Исходя из результатов исследования, мы можем предположить, что в качестве образовательного инструмента китч имеет достаточно реальные основания на реабилитацию.

С другой стороны, популярностью и предельной эксплуатацией при создании предметов китчевого искусства пользуются только те художественные артефакты, которые уже доказали свою эффективность для публики и, следовательно, для получения прибыли. Китч имитирует наиболее яркие в экспрессивном плане фрагменты высокого искусства, вычленяет из целого комплекса привлекательные элементы: «Китч насквозь академичен «...» Академичное превратилось в крахмальную манишку для китча» [2, с. 5].

Тезис также был проверен эмпирически. Во-первых, был проведен анализ предложения магазинов высокого класса и масс-маркета, а также музейные магазины. В качестве образцов были выбраны: «Луи Виттон», 
«Алиэкпресс», магазин Эрмитажа «Эрмитажный магазин» соответственно. По итогам анализа было выявлено, что, действительно, эрзацы воспроизводят довольно ограниченный, часто повторяющийся круг произведений и авторов. Особенно излюбленными являются: Ван Гог, да Винчи, Малевич, Врубель, Климт, Тициан, Ян Вермеер, Эдвард Мунк и другие. Во-вторых, уже упоминавшаяся нами референтная группа подверглась второй части исследования, в ходе которого ей были предложены имена полиматов эпохи Возрождения Леонардо да Винчи и Леона Баттиста Альберти, а также картины «Звездная ночь» и «Едоки картофеля» Ван Гога. Выбранные деятели и полотна кажутся нам равнозначными в своих парах в контексте достижений в области науки об искусстве и художественных достоинств соответственно. Результаты показали, что абсолютное количество опрашиваемых было знакомо с да Винчи и хотя бы частью его наследия, а также с полотном «Звездная ночь» Ван Гога, в то время как с не пользующимися популярностью в китчевой культуре Л.Б. Альберти, его наследием и полотном «Едоки картофеля» Ван Гога были знакомы не более двух и пяти человек соответственно.

Таким образом, приобщение молодёжи происходит только к ограниченному кругу артефактов, а потому не способно повысить осведомленность и уровень знаний об искусстве. Избирательность явления приводит к искажению воспитания адекватного художественного вкуса посредством творческой дискриминации художников и произведений искусства.

Так, типичной для Лувра является многолюдность в зале, где экспонируется Джоконда. Картина защищена пуленепробиваемым стеклом и висит отдельно от других. Однако недалеко от неё находятся ещё два полотна - «Мадонна в гроте» и «Анна, Мария, младенец и агнец». Они помещены без всякого стекла, так как публика не оказывает им такого внимания, как Джоконде. Опрос референтной группы относительно трёх приведённых выше полотен имеет следующие результаты: более половины представителей никогда не были знакомы с двумя последними картинами, подавляющее большинство оставшейся части опрашиваемых видели картины, но не знали ни их автора, ни название, меньшинство или были знакомы только с изображением, или знали автора и название. Так, соотношение оказалось следующим: тридцать один к одиннадцати к восьми соответственно. 
Творческая дискриминация становится одной из причин невозможности воспитания адекватного художественного вкуса посредством китча. Опрошенные, не обладая выработанной способностью к анализу произведения, среди предложенных им артефактов, часть из которых не заимствуется культурой китча, а другая - используется в качестве эрзацов регулярно, стабильно отдавали предпочтение растиражированным предметам искусства, хорошо знакомым им, что свидетельствует о неспособности группы оценить художественные достоинства тех предметов, которые не являются привычными, а также об отсутствии эстетического чувства.

Ещё одна проблема ознакомления молодёжи с искусством посредством китча кроется в неспособности последнего проникнуть в глубинные смыслы авторского замысла и объяснить его. Так, подавляющее большинство представителей референтной группы - сорок восемь из пятидесяти - были осведомлены относительно названия и автора полотна «Черный квадрат» К. Малевича, что во многом является заслугой культуры китча. Тем не менее, художественная концепция мастера была известна лишь двум представителем из пятидесяти опрошенных. Неспособность китча улучшить качество знания его потребителей была отмечена Н.А. Дмитриевой: «Сноб, восхищающийся «шоковыми» произведениями Пикассо за то, что они щекочут нервы и компенсируют недостающие в жизни острые ощущения, отнюдь не вникает в их истинный разрушительно-созидающий смысл» [3, с. 102].

Таким образом, художественная культура впервые преподносится молодым поколениям исключительно в виде усредненных форм, эрзацев. Но, во-первых, попытка современного прочтения художественного наследия неизбежно приводит к смысловому нарушению композиционной целостности и авторского замысла, при котором любое произведение искусства становится антихудожественным. Во-вторых, как уже отмечалось, китч был создан носителями невзыскательного художественного вкуса для удовлетворения соответствующих потребностей, а потому он априори не может формировать адекватное эстетическое чувство. Так, усредненные критерии предпочтений и вкусовых пристрастий становятся образцами для подражания, ориентируя на сравнительно низкий уровень культурных запросов. В-третьих, китч отражает тот спектр эмоций, который привычен человеку, а значит, не может развить чувственное восприятие, так как китч лишь имитирует воздействие искусства. Другими словами, между автором произведения и зрителем не может происходить диалог, а потому нарушается процесс единства рефлексии и 
трансценденции, при котором зритель, осознавая свою позицию, тем самым её определяет и ограничивает, благодаря чему становится способным видеть вне её рамок, расширяя свой эмоционально-ценностный опыт. Китч связывается с массовым сознанием и отвлекает человека на пустое, в то время как истинное искусство требует включенности в осмысление произведения.

Таким образом, китч становится суррогатом искусства для невзыскательного потребителя, стремящегося быть приобщённым к элитарному искусству и наслаждаться его красотой, но не желающего терять себя в напряженном поиске знания и напрягать собственный интеллект и эстетическое чувство.

Кроме того, важным последствием взаимодействия молодёжи и эрзацев является набирающая обороты тенденция демократизации культуры и её оценки, а именно воспитание китчом толерантности в вопросах оценки художественной культуры любого уровня.

Явление определяется спорно. С одной стороны, демократизация позволяет избегать случаев резких, необоснованно критических суждений относительно творческих проявлений. Кроме того, приобщенность к искусству и толерантность в оценке рождают полярность суждений, что зачастую способствует развитию конфликтующих течений, появлению свежих взглядов. Благодаря средствам массовой информации и различным интернет-площадкам, люди делятся знаниями об искусстве, догадками и своим мнением.

С другой стороны, демократизация элитарного искусства приводит к загрязнению информационного поля искусствознания, негативно влияя на развитие гуманитарной сферы. Актуальность данного феномена повышается в последние годы в связи с развитием средств массовой информации, в основном интернета. Так, человек, не имеющий фундаментальных знаний о произведении, художественном течении, эпохе, воспринимая демократизацию культуры буквально, делится в сети интернет не только эмоциями от увиденного, но и своими умозаключениями и оценками, не основанными на знании, что иногда перерастает во всеобщее заблуждение.

Так, Википедия, общедоступная мировая интернет-энциклопедия, являющаяся одним из самых распространенных источников информации для среднестатистического человека, не связанного с конкретной наукой, хранит устоявшиеся фактические ошибки, ставшие истиной для неискушённого зрителя. Например, «Демон Летящий» является «частью серии иллюстраций 
к поэме М.Ю. Лермонтова «Демон» по информации, приведенной в упомянутом источнике.

Кроме того, загрязнение информационного поля происходит и посредством других интернет площадок, например, крупнейшего видеохостинга в мире «Ютьюб», где создано множество каналов, транслирующих знания об искусстве. На одном из таких, позиционирующем себя как альманах, количество подписчиков которого достигло полумиллиона и неуклонно растёт, помимо действительно расширяющих кругозор зрителя видео, есть те работы, которые дезориентируют потребителя: никем не контролируемый, создатель контента может выдать субъективное мнение за реальные факты. Так, в одном из видео контентмейкер убеждает полумиллионную аудиторию в том, что К.П. Брюллов на всех картинах рисовал голую грудь в угоду императору, осуждает его за отсутствие кровавых сцен, не учитывая направление, в котором работал художник, обвиняет в не реалистичности и артистичности, а также уличает в политическом заискивании перед Николаем Первым. Проблемой становится ещё и то, что такие лидеры мнений мотивируют допущение вольного толкования собственным мнением и свободой интерпретации предметов искусства, не осознавая ответственность перед потребителем, не задумываясь над проблемой загрязнения информационного поля в искусствознании и не беря в расчет необходимость сепарации чувств к творцу от объективных фактов.

Кроме того, в связи демократизацией элитарного искусства, его мнимой доступностью, а также вульгаризацией происходит падение уровня значимости самих артефактов. Китч влияет на общую иерархию ценностей, нивелирует принцип элитарности. А. Моль отмечает: «Обычная система, которая воспринимает произведение искусства благоговейно и представляет его массовому обществу как образец, изготавливая из него репродукции в качестве эрзаца, включает инфляционный процесс, который мало-помалу разрушает произведение и делает из него элемент»[4, с. 277]. Тиражируемость приводит к обесцениванию искусства: если раньше художественный артефакт рассматривался как предмет уникальный и неповторимый, то теперь он стал доступен для масс, приобщен к их культурным ценностям, что неизбежно привело к трансформации его статуса.

Яркой иллюстрацией девальвации классических образцов и изменения отношения к ним становится то, на предметы какого назначения помещаются 
элементы произведений искусства. Так, одним из самых покупаемых предметов в уже упоминавшемся нами магазине масс-маркета «Алиэкспресс» является пара носков, украшенная, например, портретом с лицом Ван Гога. Кроме того, после изучения экспонатов, представленных на международном конкурсе Рейксмузея, были найдены, например, украшенные картинами с изображением Адама и Евы упаковки средств контрацепции. Н.А. Дмитриева приводит и такой пример: «Персонаж одного из романов Олдоса Хаксли, вспоминая, что в «приюте порока», который он посещал, на стенах висели репродукции в рамочках с картин Альма Тадемы, размышляет: «Восхитительная ирония - эти картины, которые в викторианскую эпоху рассматривались как искусство, у современного поколения стали украшением спален публичных женщин!» [3, с. 102]. Таким образом, эксплуатация предметов элитарной культуры, безусловно, накладывает отпечаток на взаимоотношения человека с ней. В связи с тем, что эрзац-культура является выгодной коммерчески, используемые образцы искусства претерпевают адаптацию, усреднение, профанацию их содержания.

Искусство начинает восприниматься в качестве пассивноразвлекательного досуга, что обуславливает положительные оценки и высокий интерес со стороны общества. Как нельзя успешнее этому способствовало развитие средств массовой информации: рекламы, периодики, интернета, кино. Популярность моды на искусство у молодежи находит отражение в деятельности и других коммерчески настроенных производителей, усугубляющих последствия китча. Например, после выхода клипа Бьенсе, снятого в Лувре, был разработан экскурсионный маршрут, включающий конкретно те артефакты, которые были использованы певицей. Таким образом, с одной стороны, молодежь действительно была привлечена к посещению музея и знакомству с произведениями искусства, с другой стороны, во-первых, артефакты выступили как объект моды и развлечения, во-вторых, были выбраны те предметы, которые уже успешно зарекомендовали себя в качестве одних из главных образцов для китча, то есть вновь послужили для успешной коммерческой деятельности.

Многие рефлексирующие о последствиях китча и его соответствие уровню дилетантизма искусствоведы, культурологи и философы понимают, что борьба с ним невозможна и бессмысленна. Мнения о способах нивелировки последствий явления также полярны. С одной стороны, даже тогда, когда государство старается упоминать об искусстве и призывает 
уважать искусство, а не китч, последний продолжает пользоваться спросом. С другой стороны, государство имеет большее количество рычагов сведения отрицательных последствий явления к минимуму, чем оно использует. Так, должно проводиться государственное регулирование культуры: прививание высоких образцов искусства и организация просветительских практик. Кроме того, надежды на оздоровление культурного климата могут быть связаны с китчевым искусством, которое доступно большинству людей, что можно свести к тезису о необходимости использования реалий современности. Так, нет смысла отрекаться от лидеров мнений молодежи, интернета и телевидения, но можно извлечь из связи с ними возможности для нивелирования отрицательных последствий китча, так как, кроме негативных черт, он обладает и позитивными, объясняющими причины устойчивости востребованности явления среди молодёжи. Попытка установления связи с лидерами мнений была впервые проведена в 2012 году Сергеем Милоновым, но практика не получила дальнейшего развития.

Таким образом, в условиях роста китча недостаточно иметь расположенность к искусству - к нему и к знаниям о нем необходимо испытывать стремление и страсть, которые дадут способность не вестись на подделки и эрзацы. Китч вводит в заблуждение. Он может быть опасен не только для обывателя, но и для того, кто только начинает свой путь в искусствознании. Хотя китч существовал действительно на протяжении всей истории искусства, такого глубокого разрыва между искусством и китчом не было вплоть до эпохи капитализма, принесшей с собой поток поддельных художественных ценностей, наводнивших мир эрзацами: «Только в новейшие времена проблема «плохого вкуса» неожиданно обернулась серьезной социальной проблемой»[3, с. 102].

\section{Список литературы}

1. Варакина Г. В. Китч как норма современной культуры // Культура и цивилизация. - 2014. - № 5. - С. 10-19.

2. Гринберг К. Авангард и китч. Пер. Калинин А. // Художественный журнал. - 2005. - № 60 .

3. Дмитриева Н. А. В поисках гармонии. Искусствоведческие работы разных лет. // Прогресс-Традиция. - 2009.

4. Моль А. Художественная футурология. К роли китча и копии в социальноэстетическом развитии // Борев В.Ю., Коваленко А.В. Культура и массовая коммуникация. М., 1986. 
5. Бодрийяр Ж. Общество потребления. Его мифы и структуры. М.: Культурная революция; Республика, 2006, с. 144-146

6. Кондрадова Н. А. Кич как социокультурный феномен - Режим доступа: https://www.dissercat.com/content/kich-kak-sotsiokulturnyi-fenomen

7. Поляков А. Ф. Духовно-нравственных потенциал китча в контексте современности - Режим доступа: https://cyberleninka.ru/article/n/duhovnonravstvennyy-potentsial-kitcha-v-kontekste-sovremennosti

8. Поляков А. Ф. Трансформация китча во Времени и Пространстве Режим доступа: https://cyberleninka.ru/article/n/transformatsiya-kitcha-vovremeni-i-prostranstve

9. Фетисова Т. А. Кич как феномен культуры. Обзор - Режим доступа: https://cyberleninka.ru/article/n/kich-kak-fenomen-kultury-obzor

10. Яковлева А.М. Китч или немного о дурном вкусе // Искусство. 2001. - № 8 .

( Д. И. Фирсова, 2020 